\title{
The role of entrepreneurship in regional development strategies (based on the Polish National Strategy of Regional Development 2010-2020)
}

\author{
Monika Plaziak, Tomasz Rachwal \\ Department of Entrepreneurship and Spatial Management \\ Institute of Geography \\ Pedagogical University of Cracow, Poland \\ mplaziak@up.krakow.pl, T.Rachwal@up.krakow.pl
}

\begin{abstract}
Entrepreneurship is one of core social and economic development factor in spatial systems, particularly at regional scale. This article presents results of analyses focused on the place and role of entrepreneurship in the regional development policy in the light of the National Strategy of Regional Development 2010-2020: Regions, Cities, and Rural Areas for Poland (the NSRD 2010-2020). Furthermore, key concepts of the Strategy were contrasted with entrepreneurship-related concepts presented in the regional development strategies of two other countries - Finland i.e.: Finland's Regional Development Strategy 2020 (FRDS 2020) and Bulgaria: The National Regional Development Strategy of the Republic of Bulgaria for the period 2005-2015 (NRDS 2005-2015). The analysis leads to a conclusion that the role of entrepreneurship in the Polish regional development strategy is underestimated compared to the position it has in the Finnish and Bulgarian strategies; thus, it is necessary to increase its importance not only in the key assumptions of the strategy but also when implementing these principles of the regional development policy in practice.
\end{abstract}

Keywords: entrepreneurship, Europe, Poland, regional development, regional policy, strategy.

\section{Introduction}

Entrepreneurship is one of the basic factors stimulating social and economic development in spatial systems at local, regional and national level. In this context, entrepreneurship is a personal feature to larger extent, i.e. an attitude adopted by a creative person capable of active participation in the social and economic life, and a feature of entrepreneur's character, i.e. the ability and willingness to set up and run one's business. It can also be a function of managerial activities. This topic has been widely covered by the literature, including works by some geographers (see Cori 1989; Acs \& Armington 2004; Kurek \& Rachwał 2009, 2011; Kola-Bezka 2010; Acs 2010; Fritsch 2011; Wyrwich 2012; Zioło \& Rachwał 2012; Makieła 2013; Qian et al. 2013). It is believed that development of both entrepreneurial attitudes and entrepreneurship interpreted as emanation of entrepreneurs and managers' activity into the society is an economic development factor of particular importance in the countries whose economy is undergoing transformation. Their major role is accelerating the economic 
growth and alleviating consequences of structural unemployment through self-employment of the unemployed. In addition, citizens' entrepreneurial attitudes are linked to creativity and the ability to implement new business ideas, which, in turn, support development of innovation considered one of the core pillars of the social and economic development and competitiveness of regions in the process of building knowledge-based economy (Gal 2005; Borowiec et al. 2009; Dorocki \& Jenner 2009; Golejewska 2012; Rachwał 2012; Zioło 2012; Makieła 2013; Perło \& Dębkowska 2013).

In this context, it is important to ask about the position which entrepreneurship occupies in regional development strategies. The article provides a detailed analysis of the place and importance attached to entrepreneurship development issue in the National Strategy of Regional Development 2010-2020: Regions, Cities, and Rural Areas for Poland (NSRD 2010-2020). In addition, the key concepts of the Strategy were compared to entrepreneurship-related concepts presented in regional development strategies of two countries - Finland i.e.: Finland's Regional Development Strategy 2020(FRDS 2020) and Bulgaria: The National Regional Development Strategy of the Republic of Bulgaria for the period 2005-2015 (NRDS 2005-2015). Finland was chosen for comparison as it is one of the most innovative and entrepreneurial countries in Europe; on the other hand, the choice of Bulgaria was based on the fact that it is a Central and Eastern European country which, similarly to Poland, continues transforming its economy. In addition, Bulgaria has fairly recently joined the EU structures. The three analysed countries have different profiles in terms of entrepreneurship development depending on the degree of the socio-economic progress and development policy objectives. In Finland, entrepreneurship is a key object of economic policy and the profile of national economy is determined by three key components: 1) activation of entrepreneurial young people, 2) increase the competitiveness of the regions, 3) the competitiveness of the country in Europe. Bulgaria is backward in terms of socio-economic progress compared to other EU countries and the development policy specifies the ways to improve the level of entrepreneurship. As for Poland, in terms of socio-economic progress and entrepreneurship development measured by the dynamics of the establishment of enterprises, it ranks between the two above mentioned countries. In the ranking related to the ease of doing business Poland also ranks between Finland and Bulgaria (Finland - position 12, Poland - 45, Bulgaria - 58, according to Doing Business 2014 report). And its development policy is focused on the efforts to solve socio-economic problems, especially unemployment, also through the development of entrepreneurship. The comparative analysis leads to the conclusions based on experiences of other countries for the Polish regional development policy.

\section{Entrepreneurship and its role in regional development}

Entrepreneurship is a very complex concept with many definitions (Brzozowski 2007; Wach 2013). According to K. Wach (2012) the scientific research offers at least four main approaches to entrepreneurship:

- entrepreneurship as a personality function (attitude),

- entrepreneurship as a function of private entrepreneurs (including an intention to start and run one's business),

- entrepreneurship as a function of micro, small and medium-sized enterprises,

- entrepreneurship as a function of managerial activities.

Furthermore, the literature in the field refers directly the term "entrepreneurship" to multi-scale spatial systems which are local government entities. In this context, a question arises whether the 
term "entrepreneurial region" (a city/town or a municipality) is appropriate or, as observed by W. Jarczewski (2007), it should rather be interpreted as an "entrepreneurial spirit" of the governing bodies and authorities of the spatial entities. So far, the latter interpretation prevailed in the literature in the field when it comes to the adjective "entrepreneurial" used to describe regional and local systems. On the other hand, the wording "an entrepreneurial region" is also used. A European initiative of the European Entrepreneurial Region contest is a good example of such interpretation. Every year, the initiative identifies and awards not more than three EU regions which offer outstanding entrepreneurial visions, irrespective of their size, wealth and competences. The regions offering the most convincing and forward-thinking strategy will have the right to use "Entrepreneurial Region of the Year" label.

As observed by Z. Zioło and T. Rachwał (2012), entrepreneurship played an important role in regional and local development because of a growing importance of entrepreneurs in the management and administration. The entrepreneurs make decisions on the location and development direction of enterprises which, through their relations in the spatial systems, affect their development or recession. Processes of social, economic and cultural transformations in different types of spatial systems are initiated by decisions based on entrepreneurial efforts of specific individuals or teams, including entrepreneurs and representatives of local and state government authorities. This way, entrepreneurship may be perceived as one of the main triggers of a change which enhances and builds a competitive advantage of regional systems.

In addition, it should be noted that the EC classified entrepreneurship to the pool of eight key competences required in lifelong learning, on a par with such competences as communication in one's mother tongue and foreign language competence, mathematical competence and basic competences in science and technology (Recommendation... 2006). An extensive definition of this competence called "a sense of initiative and entrepreneurship" has been offered. The EU recognised very high importance of developing this one as well as other key competences at each level of education and lifelong learning policies. With this awareness the EU member states move to offer entrepreneurship education at lower levels of their educational systems, as well as the academic level, in various types of studies other than economics and economics-related studies (Kurek \& Rachwał 2009; Borowiec \& Rachwał 2011; Berger et al. 2012; Płaziak \& Rachwał 2013; Wach 2013).

\section{Entrepreneurship in the Polish Regional Development Policy and the content of the NSRD 2010-2020}

The importance of entrepreneurship in the regional development was recognised as the essence of the Polish regional development strategy. The strategy is based on the new paradigm of the regional policy which introduces new regional policy principles and tools. Instead of focusing on subsidies and public aid addressed to the regions reporting slower growth under the existing old model policy, the strategy appreciates instruments such as development of business environment elements (including integrated soft and hard components and the social capital, networking and coordination) and emphasises their leading importance. Furthermore, the new paradigm takes new actors into account. So far, the key actors of the regional policy were the government and the local government of the region. At present, next to all levels of the administration and social actors, representatives of business environment were taken into account (NSRD 2010-2020: 16). The NSRD discusses in detail the issue of changing the regional policy paradigm in Poland and other European countries, 
which was also analysed and evaluated by many authors (including Szlachta 2010; Dąbrowski 2011; Lewandowski 2011; Korenik 2012), also in the important context of implementing the cohesion policy (Kudełko 2011; Rynio 2011).

However, the fact that the role of entrepreneurship was finally recognised in the regional development has not led to including it among 11 challenges. The formulas of all the challenges miss even a single reference to the development of entrepreneurship. It is only in the matrix showing interrelations of the strategic (territorial and sectoral) challenges that the intensification of business, education, science and cultural relations was taken into account as the final product of the relation between enhanced growth and employment creating potentials of the most important urban centres and a higher quality of work resources (NSRD 2010-2020: 23).

However, entrepreneurship is referred to in the descriptions of some strategic challenges, such as measurement assessing the degree of its advancement and the need for the advancement to progress:

- Challenge 2: Assurance of internal cohesion of Poland. Preventing excessive spatial differences, (b): Increasing development perspectives in lagging behind rural areas with the worst indicators of socioeconomic situation and the lowest level of access for inhabitants to goods and services shaping development capabilities - underdeveloped entrepreneurship defined as a relatively low number of enterprises (next to a very high employment in the agricultural sector, a very high percentage of poorly educated people with low vocational qualifications, low level of public institutions, including administration, little investment and shortage of infrastructure) is mentioned as an "unfavourable" developmental capacity coefficient (NSRD 2010-2020:29)."Poor entrepreneurship coefficients" (in parallel to unemployment and excessive employment in ineffective farming sector) are the root cause of the social issues which in turn lead to the economic degradation experienced by vast rural areas of Eastern and Northern regions of Poland (NSRD 2010-2020: 31). It is also necessary to improve access to services (including business consulting) so that the rural areas with the poorest growth prospects can reduce their gap and come closer to the national average and to the standard enjoyed by cities (NSRD 2010-2020:31).

- Challenge 2, (c): Counteracting the risk of losing the present socioeconomic functions of some urban areas and other areas - underdeveloped entrepreneurship was mentioned as one of negative economic phenomena (next to unemployment and low quality of the technical infrastructure) in the context of some urban areas (Szczecin, Łódź) and urbanised industrial areas (the Upper Silesian Conurbation) (NSRD 2010-2020:31).

- Challenge 2, (d): Increasing development potential and counteracting marginalisation of border areas - stimulation and growth of entrepreneurship by lifting restrictions which apply to movement of goods, people, capital and services, for transborder areas, in particular long German, Czech and Slovak border (NSRD 2010-2020:32).

- Challenge 5: Improvement of the quality of workforce resources - improvement in the quality of human resources should generate more links between the businesses, science and culture (clusters, networking) in large cities (NSRD 2010-2020:44).

- Challenge 8: Use of the cultural and tourist potential for regional development-development of entrepreneurship was mentioned in this context (next to generation of new jobs, improvement in the quality of life of local communities, increased competitiveness of regions) as an element increasing the social and economic growth rate of the state resulting from developing tourist functions based on cultural and environmental assets (NSRD 2010-2020:51). 
Entrepreneurship was mentioned in the footnotes only in relation to the regional policy principles as a feature having a decisive impact on sovereignty of a person (next to civil and economic liberties, the right to autonomy and self-fulfilment, the feeling of responsibility for the quality of one's own life and for the common good, social and political activity supporting democratic governance) which is one of determinants of a democratic society (NSRD 2010-2020:59).

Entrepreneurship was also taken into account in the Vision of regional development of Poland until 2020, subpoint Economic, social and territorial cohesion - entrepreneurship (coupled with a growth of economic activity, influx of investment, improvement in the quality and number of jobs) is expected to flourish in areas reporting the lowest social and economic advancement by supporting urbanisation processes, improvement in the quality of education and offering a broader access to public services (NSRD 2010-2020:67).

Out of the three clearly defined regional policy goals set to be delivered by 2020 , the entrepreneurial aspect was signalled in the description of the goal no 1. Support for the growth of competitiveness of regions ("competitiveness"). It requires a horizontal support for growing competitiveness of all regions leading to functional integration of these regions. The support will address the areas outside the operating regional centres and will also lead to increasing attractiveness of these regions to investors and business environment institutions (NSRD 2010-2020:71). Entrepreneurship is also mentioned in a description of the goal no 3. Creating the conditions for efficient, effective and partnership implementation of development activities targeted at territories ("efficiency"). In order to improve effectiveness of the regional policy, a departure from direct aid is planned to be replaced with support for development and employment of revolving instruments (loan and guarantee funds) generating a return from investment as well as long-term social and economic benefits (NSRD 2010-2020:72).

To achieve the goal no 1. Support for the growth of competitiveness of regions ("competitiveness"), within the objective 1.2. Creating conditions for the diffusion of development processes and the increase of their absorption outside regional centres, subpoint 1.2.2. Supporting the development and significance of subregional cities, financial support to business, improvement in quality and expanding the offer of services addressed to businesses and provided by public and non-public business environment institutions was planned (the NSRD 2010-2020:82). Under 1.2.3. Fuller use of the development potential of rural areas, it is assumed that people leaving the farming sector or intending to diversify their sources of income (e.g. agrotourism, enterprises based on culinary traditions) should receive a direct support in order to increase employment. It is planned to support creation of institutional conditions in order to increase investment in sectors other than the farming sector in areas of low-competitive farming in order to increase employment in non-farming sectors, also by supporting development of enterprise incubators (NSRD 2010-2020:85). In the objective 1.3. Building competitiveness of regions - themed activities (horizontal), 7 groups of actions are included and 2 of these groups are related to development of entrepreneurship. The subpoint 1.3.3. Increasing opportunities for innovative solutions for businesses and regional institutions takes into account "a direct, popular and level playground" offered to the world of business and the leading domestic and foreign scientific and research centres. Regional centres should see a growing share of private (company) funding in R\&D financing (NSRD 2010-2020:89). In 1.3.4. Supporting the development of business environment institutions (BEI) a change in the method of supporting the existing and newly set up businesses is planned; instead of direct financing offered to enterprises, the method focuses to a greater extent on creating conditions stimulating development of enterprises and investment attractiveness (NSRD 2010-2020:89). 
Development of entrepreneurship has been included in the directions set for actions in order to implement the goal 2. Building territorial cohesion and preventing the marginalization of problem areas ("cohesion"), within the objective 2.1. Strengthening cohesion in the national structure, together with the following activities: Strengthening the existing network of cities and urbanisation supporting, growing human resources and social capital, development of infrastructural and institutional conditions for increasing investment and work efficiency. Development of human resources and social capital will be achieved by supporting development of entrepreneurship (consulting, assistance and financial support, training) (NSRD 2010-2020:94). The objective 2.2. Support to rural areas with the lowest level of inhabitants access to the goods and services determining development possibilities addressed the need to guarantee partnership relations and collaboration between the public and private sector (the authorities of all levels and the sector of enterprises), promote entrepreneurship also by supporting creation of innovative enterprises in rural areas to ensure economic diversification (NSRD 2010-2020:97). On the other hand, the objective 2.3. Restructuring and revitalisation of cities and other areas losing their previously fulfilled socio-economic functions requires support to centres (cities) which experience particular difficulties due to underdeveloped entrepreneurship. The support includes activities oriented towards supporting the quality of human capital achieved also by stimulating entrepreneurship and innovation (NSRD 2010-2020: 100). In the objective 2.4. Overcoming the difficulties related to the situation of the border areas, especially along the external $E U$ borders, support for local entrepreneurship (next to improving availability of transport and Communications services and networks) is planned to grow and promote common and popular use of the local infrastructure, protection of shared natural and cultural heritage, tourism, prevention of natural and technical hazards, support for links between urban and rural areas, reduced isolation (for residents of the neighbouring countries) (NSRD 2010-2020: 101). Higher entrepreneurial activity was mentioned among components of one of 5 success measures of the goal 2 (NSRD 2010-2020: 104).

The NSRD Implementing Authorities assume the capacity to implement integrated procedures of "complex nature". Enterprises requiring a merger of science and business are classified to such integrated procedures (NSRD 2010-2020: 148).

\section{Entrepreneurship according to Finland's Regional Development Strategy 2020}

The importance of entrepreneurship defined as business activities was already contained in the opening points of the regional development vision and, specifically, under "The economic structure of regions". It assumes that the future of Finland, its vitality as a state and in regions and other types of economic space is to be built on competitive business activities which are to form the foundation for supportive environment stimulating growth in regions. Businesses of different sizes will compete at the national and international scale and experience in international business will contribute to development of entrepreneurship in general terms in all regions of the country. SMEs are particularly important for development of regions (FRDS 2020: 14). Traditional branches of industry will grow in parallel with modern technologies while conditions will be created to support knowledge-based entrepreneurship based on modern industry - a high quality business, based on know-how and artistic creativity experience. The business will spread onto all regions (FRDS 2020: 14).

"The educational system" item of the vision mentions that entrepreneurship will be promoted at all levels of education, with a particular emphasis on entrepreneurial skills such as starting one's 
business. Different types of businesses will be presented to students; schools are to collaborate with enterprises to educate in entrepreneurship (FRDS 2020: 16).

In the Section 3 of the Strategy: "the Rationale for the vision", item 3.3. "The economic structure of regions", the opening sentence re-emphasises that the power and strength of the state and its regions will be built on strong entrepreneurship and international competitive business. Companies and businesses of different sizes will compete both on the national and international market. Businesses will be based on intensive and efficient commercial application of innovations (FRDS 2020: 24).

Entrepreneurship will effectively use natural resources of the state (such as clean water and air), creating modern types of tourist and recreation businesses based on the principles of sustainable development and environmental protection (FRDS 2020: 25).

In the subsection 3.4. "Regional labour markets" the rationale for intensifying collaboration of the system of education and the business was emphasised (FRDS 2020:25) together with the need to educate in entrepreneurship in all types of studies (FRDS 2020: 26), including shaping the readiness for entrepreneurship.

In many instances it was emphasised that entrepreneurship in Finland would grow on the basis of natural resources, in particular in the northern part of the country, offering modern tourism and recreation (FRDS 2020: 25,29), which will come with development of modern types of business in entire Finland (FRDS 2020: 30).

The Strategy identifies many alternative conditions for development of entrepreneurship. Even such problematic issue as aging society may send an impulse for business activity such as various services offered to the aging part of the society, as mentioned in the part of the Section 4. "Principles for the implementation of the strategy" (FRDS 2020: 36). This issue, which is also present in other European countries, was particularly addressed by S. Kurek and T. Rachwał (2011).

Not only the first part of the publication entitled "Finland's Regional Development Strategy", but also its second part: "Background Memorandum" refer to entrepreneurship. Both mention the importance of growing entrepreneurship in globalisation and here the highest possible diversification of types of business is essential (FRDS 2020: 41-42). Finland sees commercial and trade dealings between Russia and the EU as well as energy and mining investment in Barents' region as the opportunity to grow entrepreneurship (FRDS 2020: 43) and promote new types of climate policyoriented business (e.g. bio-energy business) (the FRDS 2020: 55, 57). In this part of the publication, a regular growth in the number of entrepreneurs in Finland was diagnosed, predominantly in the business, financial and construction service sector and, recently, also in the spheres which were so far dominated by the public sector i.e. health-care services and education as well as other social and personal services (FRDS 2020: 72). The need to continue support for growth of entrepreneurship in SMEs was emphasised. In Finland, SMEs have the largest share in the number of enterprises and are the main driving forces behind employment and creation of new jobs (FRDS 2020: 73). Another important aspect consists in reducing the average age of entrepreneurs (FRDS 2020: 73). Inadequate growth in the number of enterprises (6\%) compared to other Nordic countries (15\%) and the European average (11\%) was diagnosed, as a result of insufficient venture capital investment and entrepreneurs who are not oriented towards growing their businesses (FRDS 2020:73). Finland enjoys a relatively high share of female entrepreneurs (1/3) which exceeds the EU average. In addition, the average age of female entrepreneurs is lower than that of men entrepreneurs (FRDS 2020: 73). A share of immigrants active in business is fairly high and increasing in sectors such as accommodation, catering and business services (FRDS 2020: 73). Immigrants represent a growth potential of Finnish 
entrepreneurship (FRDS 2020: 73). Furthermore, it was found that the Finnish business environment institutions were well-developed owing to: high level of education, gender equality (equal opportunities), highly developed $R \& D$, well-operating infrastructure, pubic consulting and financial support offered to entrepreneurs. Because of low costs and little red tape the conditions for setting up a business are more favourable there than in other countries (FRDS 2020: 73). However, according to the Strategy, considering the relatively good conditions supporting growth of entrepreneurship in Finland, entrepreneurial activity is low. Furthermore, the activity varies depending on a region as a result of differentiated enterprise culture (FRDS 2020: 74).

In the light of the Finnish strategy, the government will support entrepreneurial activity involving use of renewable energy sources and activity in creative industries (FRDS 2020: 82), including culture-related activities (FRDS 2020: 84).

Entrepreneurship in rural areas and its growth was given a lot of attention, including a concept of building micro-clusters operating on the local market with regional, national and international impact in the following fields: tourism, social and health care, culture, design, local food production, RES which is expected to contribute to increasing competition of rural areas (FRDS 2020: 91). Furthermore, the legitimacy of supporting peripheral areas with more funds allocated to developing entrepreneurship was emphasised (FRDS 2020: 126). Support to a more extensive variety of business types should be offered as well as a support for on-the-job type of training and business consulting (FRDS 2020:127). The Strategy requires a higher leverage from the geographic and geopolitical location of Finland as an important state in the Baltic Sea region and a transit country to Russia (FRDS 2020: 134, 139, 142).

\section{Entrepreneurship in the provisions of the National Regional Development Strategy of the Republic of Bulgaria, 2005-2015}

In the first part of the Strategy, which offers a comparative analysis of the social and economic development status of Bulgarian regions, the subsection 1.4. "Factors determining growth rates, employment and competitive capacity" enumerates several core groups of development factors. Factors such as: human resources; R\&D, technologies and innovations; investment, energy sector; transport infrastructure and transport accessibility are listed next to entrepreneurship and development of business services. It is mentioned that Bulgaria's entrepreneurship is less developed compared to the rest of Europe and it is in need of a stronger social support for entrepreneurship (NRDS 2005-2015:19) and more entrepreneurial attitudes. In addition, an analysis of regional and structural differentiation of entrepreneurship was presented (NRDS 2005-2015: 19). The Bulgarian enterprise sector is dominated by SMEs, typically located in agglomerations and more developed regions with sectoral differentiation (NRDS 2005-2015:19). Recently, following the economic transformation of Bulgaria, both the number of enterprises and the number of business environment institutions is growing. These are organisations offering financial and insurance assistance, information and consulting services and real property and commercial (trade) services. The number of staff in these institutions/organisations is increasing. Regional agencies and business centres supporting entrepreneurs are being set up all over Bulgaria and the regional policy of Bulgaria is now facing a challenge of ensuring their sustainable growth (NRDS 2005-2015: 19, 20).

In the SWOT analysis used for formulating the strategic goals and priorities of the Strategy, entrepreneurship has been included in all 4 components and configured as follows: 
- Strengths: "Development of entrepreneurship and emergence of SMEs", "Trend towards positive changes in the business environment";

- Weaknesses: "Not fully developed and insufficiently effective business structure";

- Opportunities: "Expansion of information technology applications at a global scale (i.e. new opportunities for business management)";

- Threats: "Underdeveloped entrepreneurship due to inadequate skills level and general economic environment" (NRDS 2005-2015: 50).

In the section 2. "Concept for the spatial development of the national territory", subsection 2.1. "Development of the settlement network and urban structure in the long-term perspective", the particular role played by development and promotion of entrepreneurship in the leading centres of peripheral areas was emphasised. While these centres are, by no means, large cities, they are "the driving motors of regional development" in the regions (NRDS 2005-2015: 52). On the other hand, the subsection 2.3 "Improvement of the state of the environment of areas with cumulative environmental problems" when listing several methods for solving local issues, such as: "spatial planning", "programming", "technical and institutional measures", mentions also "partnership with business and the citizens". Spatial planning and development of environmentally unsound areas must go hand in hand with the partnership of local administration, business and residents. It is only such partnership that can bring measurable benefits (NRDS 2005-2015: 62, 64).

In the Section 3. "Vision, goals, and priorities of regional development", subsection 3.2. "Strategic goals", sustainable development of regions was set as the goal and one of its strategic objective is development of planning regions of Bulgaria by investing into fixed (tangible) assets (the infrastructure) and into human capital, against the means of EU regions. A long list of actions listed in the section (such as restructuring the regional economy, supporting knowledge-based economy, increased access to employments related to improvement in the quality of education offered to the labour force, adjustment of the labour force to the needs of regions, technological progress), development of the regional and local infrastructure supporting business investment came last (NRDS 2005-2015:67). In the subsection 3.3 "Regional development priorities" of the priority 1. "Raising regional competitiveness on the basis of a knowledge-based economy", the objective: "Development of $R \& D$ activities, technology development and innovations in the regions" mentions the need to support entrepreneurship such as setting up technological parks and enterprise incubators to improve the quality of R\&D and education and develop new technologies. However, education for entrepreneurship was not mentioned (NRDS 2005-2015: 70). In the objective 2. "Building of business networks and regional and cross-border clusters" of the same priority, it was emphasised that, in Bulgaria, development of business networks and clusters was rather poor and, consequently, the regional policy was oriented towards developing such networks and clusters. Development of the public sector acting as a catalyst in the process of cluster development is emphasised. Clusters should be as much differentiated as possible, with the emphasis on supporting education. However, no education for entrepreneurship was taken into account (NRDS 2005-2015: 70, 71). Furthermore, the priority mentions the need of access to IT technologies, in particular, in the public sector and in the entrepreneurship sector, primarily from the SMEs (NRDS 2005-2015:71). In the priority 2. "Development and improvement of the infrastructure to create conditions for growth and employment" development of the regional and local infrastructure was classified to the key business development factors (NRDS 2005-2015: 72). In the objective 3. "Improvement of the access to and construction of regional and local business infrastructure" of the priority, poor availability of local business supporting services was 
emphasised again, in particular in less developed regions. This is where the main investment impact should be directed in the form of regional consulting desks for investors, enterprise incubators, business centres, special enterprise and industry development zones (NRDS 2005-2015:73). In the priority 3. "Raising the attractiveness of and quality of life in the planning regions" the goal 1. "Raising the attractiveness of the regions through investments in education" emphasised the need for partnership of business, education and R\&D sectors. It's about an educational offer aligned to requirements of employers, including entrepreneurship, which, effectively, is a cry for qualified labour force. But, again, entrepreneurship in education was not mentioned (NRDS 2005-2015:74). In the objective 2. "Integration of the entire territorial community in the labour market", in reference to the priority, there are provisions on the requirement to support the entrepreneurs introducing new technologies in farming to reduce the excessive employment in the sector and the need to support new and planned businesses as well as the self-employed, with a particular emphasis on women-entrepreneurs (NRDS 2005-2015: 75).

In the priority 5. "Development of co-operation for European spatial cohesion, promotion of partnership and good neighbourhood for the purposes of development", the objective 1. "Development of cross-border co-operation" places the need to support entrepreneurship promotion and more specialised SME development at the top of the actions (NRDS 2005-2015: 79), while, in the Section 4. "Implementation of the NRDS", the Ministry of Labour and Social Policy was mentioned as the institution responsible for development of entrepreneurship (NRDS 2005-2015: 84).

In the Annex No 4, indicators such as the number of persons trained in entrepreneurship, knowledge and skills were mentioned among indicators used to monitor implementation of the Strategy (NRDS 2005-2015:100).

\section{Entrepreneurship in the NSRD 2010-2020 against the FRDS 2020 and the NRDS 2005-2015.}

In the foundations of the regional development policy concept for Poland, there is a positive change in perceiving the role and the importance of entrepreneurial activity in support for the overall development of the country and the society. It comes as an element of a new regional policy paradigm, which takes into account a change in regional policy instruments, including a focus on a growing business environment. The policy concepts introduce new actors to the implementation of the policy, including representatives of business. However, a detailed analysis of the content of the NSRD disclosed that the importance of the issues was not emphasised as they were not directly included in the text (names, titles) of challenges, goals and actions, except for 2 actions: 1.3.3. Increasing opportunities for innovative solutions for businesses and regional institutions, 1.3.4. Supporting the development of business environment institutions (BEI). However, references to the demand to develop entrepreneurship can be found in descriptions of challenges, objectives and directions of actions, which are full of details. Unfortunately, it is quite often that they are rather general and fail to offer or suggest any specific proposed solutions. In the NSRD, a particular attention was paid to developing entrepreneurship in rural areas, in particular in the areas where the development is impeded; relatively much space was given to the need to support the BEI (Table 1). Unfortunately, education in entrepreneurship in any type of school as an important factor forming entrepreneurial attitudes and, in consequence, affecting development of spatial systems of different scale, was not taken into account. 
Table 1. Selected principles referring to entrepreneurship development in regional development strategies of Poland - the NSRD 2010-2020, Finland- the FRDS 2020 and Bulgaria - the NRDS 2005-2015

\begin{tabular}{|l|c|c|c|}
\hline \multicolumn{1}{|c|}{ Principle } & $\begin{array}{r}\text { The NSRD } \\
\mathbf{2 0 1 0 - 2 0 2 0}\end{array}$ & The FRDS 2020 & $\begin{array}{c}\text { The NSRD } \\
\mathbf{2 0 0 5 - 2 0 1 5}\end{array}$ \\
\hline $\begin{array}{l}\text { Development of Business Environment } \\
\text { Institutions }\end{array}$ & + & + & + \\
\hline SME development & + & + & + \\
\hline $\begin{array}{l}\text { Partnership of science }- \text { business and the } \\
\text { authorities }\end{array}$ & + & + & + \\
\hline Entrepreneurship in rural areas & + & + & + \\
\hline Entrepreneurship education & + & + & + \\
\hline $\begin{array}{l}\text { Benefiting from and using regional potentials } \\
\text { (e.g. human, social, cultural and natural potential) }\end{array}$ & - & + & + \\
\hline Entrepreneurship of women & - & + & + \\
\hline Immigrants' entrepreneurship & - & + & + \\
\hline Lowering the entrepreneurs' age & + & + & + \\
\hline
\end{tabular}

Source: own study.

In comparison to the Polish NSRD, entrepreneurship occupies a prominent position in the FRDS 2020. In the strategy, entrepreneurship is approached as one of the foundations of the Finnish economy, both at the national and regional level. Contrary to the Polish strategy, the principles of the Finnish strategy emphasise the role of education in entrepreneurship at all levels of education with a view to promoting activity and creativity in the society open to entrepreneurial efforts (Table 1). In addition, the need to reduce the average age of entrepreneurs was emphasised and immigrants' activities were indicated as an entrepreneurial potential. According to the Finnish regional development strategy, entrepreneurship should be developed on the basis of local resources such as renewable energy, innovation and natural environment attractions. Furthermore, it should be both modern and diversified to increase competitiveness of Finnish enterprises on the international arena. The need to stimulate entrepreneurship in rural areas (in the form of mini-cluster) and to continue the growth of the SME sector was emphasised. It was stressed that the peripheral geographical location of Finland does not need to stand in way to entrepreneurship development but, on the contrary, it may stimulate its growth.

The need to develop entrepreneurship was more appreciated in the Bulgarian strategy than in the Polish strategy and that is because of the entrepreneurial backwardness of Bulgaria in this respect when compared to other EU states. The Bulgarian strategy stressed development of the infrastructure in support for business development. Similarly to the Polish strategy, the Bulgarian strategy lacks any references to or mentions of education in the field of entrepreneurship in the formal system of education; it only offers some value references to courses and training. The importance of SME development, in particular in the energy and agricultural sector, was emphasised as much as the effort to achieve a differentiated SME structure similarly to principles of the Finnish strategy. Note that the strategy also refers to the need to promote entrepreneurship of women, while such reference is missing in the Polish strategy (Table 1). 


\section{Conclusions}

To sum up, note that the issue of entrepreneurship development was recognised in all three regional development strategies prepared for Poland, Finland and Bulgaria both as an important objective and a development task for the countries and their regions. However, the issues occupies the most prominent position in Finnish strategy (FRDS 2020), which identifies development of the country as a whole and development of regions with stipulating and growing entrepreneurial attitudes and activity of its residents. While all the strategies discussed in this paper refer to the need to use these potentials in the enterprise development context, the Finnish strategy contains the most specific regulations governing these aspects. Furthermore, these strategies have different concepts and references. The Polish and Bulgarian strategies focus on developing institutions operating in the business environment while only slightly emphasising the need to change the social awareness in this respect, as demonstrated by lack of any reference to the forms or even the need to offer education in entrepreneurship at any level of the education system. On the other hand, the aspect of entrepreneurial education has been present in reference to all levels of education. The three strategies clearly emphasise a pressing need to promote and support BEI and collaboration between the science and business and the local authorities. Furthermore, all three strategies appreciate the importance of supporting development of entrepreneurship in rural areas and, in particular, in the SME sector. It is significant that the strategies for Finland and Bulgaria touch upon the issue of promoting and growing enterprise among women and, furthermore, the Finnish strategy puts a particular emphasis on promoting enterprise among immigrants, who represent an important growth potential of the country. In addition, the strategy for Finland indicates the need to lower the average age of entrepreneurs which is closely related to steps aimed at expanding the educational offer in entrepreneurship.

The above-presented results of the analysis indicate possible application of good Finnish and Bulgarian practices for the purpose of amending and updating the Polish development strategy. On the one hand, this will effectively expand the pool of available regional policy instruments with a set of entrepreneurship-related tools, where the entrepreneurship is interpreted not only as activity of entrepreneurs but also as the attitude of residents, which can be regarded as an entrepreneurial potential (Krueger\&Brazeal, 1994). Of particular importance is to implement provisions on educating in entrepreneurship and offering such education at all levels of education as well as define relations in this respect between the regional policy and the educational policy of the state and also between regional and local educational policies of local government units responsible for different levels of education. This is a sine qua non condition to meet challenges coming from the contemporary knowledge-based economy going through the information phase of civilisation; its growth is based on competences acquired in the educational process and they include entrepreneurship knowledge, skills and attitudes of people.

In the light of the above, it seems that the Polish regional development strategy should be amended. These changes may be based on the concept of an 'entrepreneurial region' - a region with entrepreneurial visions, active in attracting external and enhancing endogenous stimuli of entrepreneurship development, in particular the SME sector, based on a system of strong links between the actors of the economic life, with efficiently operating institutions and the business environment infrastructure as well as educational institutions which implement entrepreneurship-oriented educational programmes involving employers at all levels of formal education and in the life-long learning. It should become one of the leading objectives of the Polish regional policy to build such enterprise-oriented region. It fits into all three elements of the triad: competition - cohesion - efficiency. 


\section{References}

Acs Z., 2010. Entrepreneurship and Regional Development. Cheltenham: Edward Elgar.

Acs Z., Armington C. 2004. Employment growth and entrepreneurial activity in cities. Regional Studies, vol. 38, iss. 8, pp. 911-927 [DOI:10.1080/0034340042000280938].

Berger S., Canning R., Dolan M., Kurek S., Pilz M., Rachwał T., 2012. Curriculum-making in pre-vocationaleducation in the lower secondary school: A regional comparative analysis within Europe, Journal of Curriculum Studies, vol. 44, iss. 5, pp. 679-701 [DOI:10.1080/00220272.2012.702223].

Borowiec M., Rachwał T. 2011. Kształtowanie postaw przedsiębiorczych na lekcjach geografii wyzwaniem edukacyjnym w procesach globalizacji. Przedsiębiorczość - Edukacja, vol. 7, pp. 321-332.

Borowiec, M., Dorocki, S., Jenner B., 2009. Wpływ zasobów kapitału ludzkiego na ksztattowanie społeczeństwa informacyjnego i innowacyjności struktur przemysłowych. Prace Komisji Geografii Przemysłu Polskiego Towarzystwa Geograficznego, vol. 13, pp. 95-109.

Brzozowski T., 2007. „,Przedsiębiorczośc”' - pojęcie polisemiczne czy niewłaściwie rozumiane? Próba systematyzacji. Przedsiębiorczość - Edukacja, vol. 3, pp. 196-203.

Cori B., 1989. Towards a new geography of Italian industrial entrepreneurship, Geographia Polonica, vol. 57, pp. 39-52.

Dąbrowski A., 2011. Kierunki europejskiej polityki regionalnej - wybrane problemy, Prace Naukowe Uniwersytetu Ekonomicznego we Wrocławiu, vol. 241, pp. 30-40.

DoING BUSINESS 2014. Understanding Regulations for Small and Medium-Size Enterprises. 2013, Washington: International Bank for Reconstruction and Development/The World Bank.

Dorocki S., JENNER B., 2009. Wplyw wielkości nakładów inwestycyjnych w sektorze B $+R$ na regionalne zróżnicowanie tempa rozwoju Francji. Przedsiębiorczość - Edukacja, vol. 5, 188-197.

Drejerska N., 2012. Krajowa polityka rozwoju regionalnego a programowanie rozwoju regionów. Studia i Materiały. Miscellanea Oeconomicae, vol. 2, pp. 11-20.

Finland's Regional Development Strategy 2020, 2010, Helsinki: Ministry of the Employment and Economy.

Fritsch M.,2011. Handbook of Research on Entrepreneurship and Regional Development: National and Regional Perspectives. Cheltenham: Edward Elgar.

Gal Z., 2005. A New Tool for Economic Growth: Role of Innovation in the Transformation and Regional Development of Hungary, Geographia Polonica, vol. 78, iss. 2, pp. 31-52.

Golejewska A., 2012. Innowacyjność a konkurencyjność regionalna krajów Grupy Wyszehradzkiej w latach 1999-2008. Prace Komisji Geografii Przemysłu Polskiego Towarzystwa Geograficznego, vol. 19, pp. 93-115.

Jarczewski W., 2007. Duch przedsiębiorczości w proinwestycyjnych działaniach władz lokalnych. Przedsiębiorczość - Edukacja, vol. 3, pp. 72-80.

Kola-Bezka M., 2010. Przyczynek do rozważań o przedsiębiorczości polskich regionów, Nierówności Społeczne a Wzrost Gospodarczy, vol. 16, pp. 403-411.

Korenik S., 2012. Wyzwania i dylematy współczesnej polityki regionalnej, Biblioteka Regionalisty, iss. 12 , pp. $53-62$.

Kudełko J., 2010. Rola europejskiej polityki spójności w krajowej i regionalnej polityce rozwoju, Prace Naukowe Uniwersytetu Ekonomicznego we Wrocławiu, vol. 95, pp. 223-232.

Kurek S., Rachwał T., 2009. The role of business education in the development of entrepreneurship in the member states of the European Union, Europa XXI, vol. 19, pp. 127-142. 
Kurek S., Rachwał T., 2011. Development of entrepreneurship in ageing populations of the European Union, Procedia. Social and Behavioral Sciences, vol. 19 (2011), pp. 397-405 [DOI:10.1016/j.sbspro.2011.05.100].

Krueger N.F. JR., Brazeal D.V, 1994, Entrepreneurial Potential and Potential Entrepreneurs. Entrepreneurship Theory\&Practice, vol. 18(3), pp. 91-104.

Lewandowski K., 2011. Ocena polityki regionalnej Unii Europejskiej w świetle badań empirycznych, Gospodarka w Praktyce i Teorii, vol. 2(29), pp. 53-64.

Makieła Z., 2013. Przedsiębiorczość i innowacyjność terytorialna. Region w warunkach konkurencji. Wyd. C.H. Beck, Warszawa.

National Strategy of Regional Development 2010-2020: Regions, Cities, and Rural Areas, 2013, Warsaw: Ministry of Regional Development.

Perło D., Dębkowska K., 2013. Konkurencyjność regionów Unii Europejskiej, Ekonomika i Organizacja Przedsiębiorstwa, vol. 64, iss. 6, pp. 60-70.

Qian H., Acs Z. J., Stough R. R. 2013. Regional systems of entrepreneurship: the nexus of human capital, knowledge and new firm formation, Journal of Economic Geography, vol. 13, iss. 4, pp. 559-587 [DOI: 10.1093/jeg/lbs009].

Rachwał T., 2012. Innowacyjność przedsiębiorstw przemysłowych jako czynnik rozwoju miast, [in:] Makieła Z., Szromnik A. (eds.), Miasto innowacyjne. Wiedza - Przedsiębiorczość - Marketing, Studia Komitetu Przestrzennego Zagospodarowania Kraju PAN, vol. CXLI, pp. 135-151.

Rachwał T., Płaziak M., 2013. Przedsiębiorczość w kształceniu w zakresie gospodarki przestrzennej w polskich uniwersytetach, [in:] Churski P., Kudłacz T. (eds.), Gospodarka przestrzenna - doświadczenie i wyzwania procesu kształcenia, Biuletyn Komitetu Przestrzennego Zagospodarowania Kraju PAN, vol. 251, pp. 198-263.

Recommendation of the European Parliament and of the Council of 18 December 2006 on key competences for lifelong learning, 2006. 2006/962/EC, Official Journal of the European Union, L 394, 30.12.2006.

Rynio D., 2011. Polityka spójności a nowy paradygmat polityki regionalnej w Polsce. Prace Naukowe Uniwersytetu Ekonomicznego we Wrocławiu, vol. 227, pp. 192-201.

Szlachta J., 2010, Europejska polityka regionalna po roku 2013 - wyzwania dla Polski, Prace i Materiały Instytutu Rozwoju Gospodarczego, vol. 83, pp. 215-236.

The National Regional Development Strategy of the Republic of Bulgaria for the period 2005-2015, 2005, Sofia: Ministry of Regional Development and Public Works.

Wach K., 2012, Europeizacja matych i średnich przedsiębiorstw. Rozwój przez umiędzynarodowienie, Warszawa: Wydawnictwo Naukowe PWN.

Wach, K. 2013. Edukacja na rzecz przedsiębiorczości wobec współczesnych wyzwań cywilizacyjno-gospodarczych, Przedsiębiorczość - Edukacja, vol. 9, pp. 246-257.

Wyrwich M., 2012. Regional Entrepreneurial Heritage in a Socialist and a Postsocialist Economy, Economic Geography, vol. 88, iss. 4, pp. 423-445 [DOI: 10.1111/j.1944-8287.2012.01166.x].

Zioło Z., 2012. Miejsce innowacyjności w ksztaltowaniu procesów rozwoju gospodarczego układów przestrzennych. Prace Komisji Geografii Przemysłu Polskiego Towarzystwa Geograficznego, vol. 20, pp. 9-32.

Zioło Z., Rachwał T., 2012. Entrepreneurship in geographical research [in:] Churski P. (ed.), Contemporary Issues in Polish Geography, Poznań: Bogucki Wydawnictwo Naukowe, pp. 135-155. 